Uludag Univ. J. Fac. Vet. Med. 35 (2016), 1,2: 49-52

\title{
Bir Atta Blanket'e Bağlı Kuyruk Yaralanması Olgusu
}

\author{
Mustafa Barış AKGÜL ${ }^{1}$ \\ Erhan BAŞER \\ Nihat ŞINDAK ${ }^{1}$
}

Ali GÜLAYDIN ${ }^{1}$

Özet: Bu olgu sunumu; 1 yaşlı, dişi, melez bir at oluşturmaktadır. Blanket'in atın vücut yapısından küçük olması ve üç gündür üzerinde bırakılması sonucu kuyruk altından geçen halka şeklinde kalın örgülü polyesteri andıran dokusu olan ipin sürtünmeye bağlı olarak kuyruk kaidesinin her iki yanından başlayıp alt tarafını da kapsayacak şekilde kas dokusuna ulaşacak derinlikte bir yaralanma oluşturduğu gözlendi. Küret vasıtası ile nekrotik dokular uzaklaștırıldı ve kanamalar kontrol altına alındı. Monoflament yapıda polipropilen (USP:0) bir iplik materyali ile plastik tüpler kullanılarak yatay ' $U$ ' dikişi bölgeye uyguladı ve gergin olan yara kenarlarının olabildiğince birbirine yaklaştırılması sağlandı. Dikişler uzaklaştırılana kadar her gün bir kez antiseptik sölüsyonlar ile yara pansumanı yapıldı. 10. günde bölgeden dikişler uzaklaştırıldı ve yara hattında sekonder iyileşme takip edilmeye başlandı. Yara hattının 1,5 ay sonra tamamının iyileştiği görüldü. Etiyolojik yönden ender görülen bu olgunun raporlanarak paylaşılması amaçlanmıştır.

Anahtar Kelimeler: At, kuyruk, yara.

\section{The Case of Tail Wound Depend on Blanket İnjury in A Horse}

\begin{abstract}
This case report; 1 year old, female, hybrid form of a horse. As the blanket of the horse is smaller than the body structure and form of release as a result of tail from under the ring over the last three days due to the friction of the polyester rope tail base to cover the bottom, starting on both sides have observed that an injury to a depth that reaches the muscle tissue. necrotic tissue was removed by using curette and bleeding was controlled. the horizontal stitch using a fiber material Monoflament Polipropilen (USP:0) and plastic tube was applied stitches and the wound edges was achieved strained approximation as possible to each other.

Once daily it was wound dressing with antiseptic solutions. Until the stitches removed after ten days the stitches were removed and the wound began to be tracked line secondary healing. After 1.5 months it was observed that all of the line wound was healed. We aimed to share this case which has rare etiological.
\end{abstract}

Key Words: Horse, tail, wound.

1 Siirt üniversitesi, Veteriner fakültesi, Cerrahi Anabilim Dalı, Merkez Kampus, Güres Cad., Siirt, Türkiye. e-posta: mbakgul@hotmail.com 


\section{Giriş}

Yumuşak dokuları oluşturan öğelerin kesici, yaralayıcı veya bunlara benzer araç ve gereçlerle birbirinden ayrılması olgusuna yara denir. Daha açık ve özlü bir tanımlamayla, yumuşak dokuların bütünlüğünün bozulması olayidir ${ }^{6}$.

Yara iyileşmesi akut inflamasyon, proliferasyon ve yeniden şekillenme aşamalarından oluşmaktadır ${ }^{7}$. Bu aşamaların dışarıdan gözlenmesi zordur. Pratikte ise makroskopik bulguların gözlenmesiyle yara iyileşmesi yang1, granülasyon dokusu oluşumu, yara kontraksiyonu ve epitelizasyon aşamalarından oluşmaktadır ${ }^{7}$.

Yaraların sağaltımı ve korunması atlarda kolay değildir. Koruyucu bandaj uygulamalar1nın özellikle ekstremitelerin proksimalinde ve vücut üzerinde uygulanması zor olabilir ${ }^{8}$. Koruyucu önlemlerin alınamadığı durumlarda bakteriyel kontaminasyon riski artar ve yara iyileşmesinin gecikmesine yol açabilir ${ }^{1}$. Yara debritmanının yapılması bölgedeki bakteri sayısını azaltmada ve nekrotik dokuları uzaklaştırmada etkili bir yoldur. En yaygın türleri mekanik, kimyasal ve otolitiktir 5 . Özellikle yara hattın birbirinden uzaklaşmıș ve karșı karșıya getirilmesi zor olan yaralarda çeşitli destek dikişleri tanımlanmıştır. Bunlardan biri olan plastik tüplerle uygulanan yatay ' $U$ ' dikişidir' .

Kışlık blanketler çok kalın ve genellikle yumuşak kumaştan yapılırlar, atın vücudunda, sabit kayıșlar sayesinde bağlanırlar. Örtü ayını zamanda atın tüylerinin temiz kalmasını sağlar, fakat örtünün kendisi çabuk kirlenir ve düzenli bir şekilde yıkanması gerekir. Yazlık blanket, çok ince ve pamuktan yapılmıştır. Atın yazın çalışmasından sonra terleme sonucu üşütmesini engellemek için konulur. Örtü hafif olduğu için, terin buharlaşmasını sağlar².

$\mathrm{Bu}$ çalışmada atlarda yalnış blanket uygulamas1 sonucunda kuyruk kaidesinde oluşan yaralanmanın, atlarda yaralanma konusun da ilginç ve yetiştiricilik açısından önemli bir etiyolojik faktör oluşundan dolayı sunulması amaçlanmıştır.

\section{Olgu Sunumu}

$\mathrm{Bu}$ olgu sunumu; 1 yaşl1, dişi, melez bir at oluşturmaktadır. Anamnezde üç gündür blanket'in üzerinde olduğu ve blanket'in kuyruk altından geçen ipinin kesmesi sonucunda kuyruk kaidesinde yara oluşmuş olduğu söylendi.
Blanket'in atın vücut yapısından küçük olması ve üç gündür üzerinde birakılması sonucu kuyruk altından geçen halka şeklinde kalın örgülü polyesteri andıran dokusu olan ipin sürtünmeye bağlı olarak kuyruk kaidesinin her iki yanından başlayıp alt tarafinı da kapsayacak şekilde kas dokusuna ulaşacak derinlikte bir yaralanma oluşturduğu gözlendi. Bölgenin üzerine yabanc1 cisimler ile bulaşık olduğu saptandı. Yara kenarlarının kontraksiyonuna bağlı olarak yara açıklığının arttığı ve dokuların ödemli, hafif kanamalı olduğu saptand. Hastaya detomidin hidroklorid $0.7 \mathrm{ml}$ intravenöz yolla uygulanarak sedasyona alındı. Ardından povidone iodine solüsyonu (10:1000 ml serum fizyolojik) kullanılarak bölgenin antisepsisi sağlandı. Küret vasıtası ile nekrotik dokular uzaklaştıııldı (Şekil 1). Kanamalar kontrol altına alındi. Monoflament yapida polipropilen (USP:0) bir iplik materyali ile plastik tüpler kullanılarak yatay ' $U$ ' dikişi bölgeye uyguladı ve gergin olan yara kenarlarının olabildiğince birbirine yaklaştırılması sağlandı (Şekil 2). Penicilin türevi bir antibiyotik seçimi yapıldı ve 7 gün uygulandı. Dikişler uzaklaştırılana kadar her gün bir kez antiseptik sölüsyonlar ile yara pansumanı yapıldı. 10. günde bölgeden dikişler uzaklaștırıldı ve yara hattında sekonder iyileşme takip edilmeye başland1 (Şekil 3). 10. günden itibaren yara bölgesi iyileşinceye kadar her gün yara pansumanı antiseptik solüsyonlar ile yapıldıktan sonra bölgeye madecassol ve furacin pomad tatbik edildi. Belirli aralıklarla taşkın granülasyon dokusuna küretaj işlemi uygulandı. Yara hattının 1,5 ay sonra tamamının iyileştiği görüldü (Şekil 4).

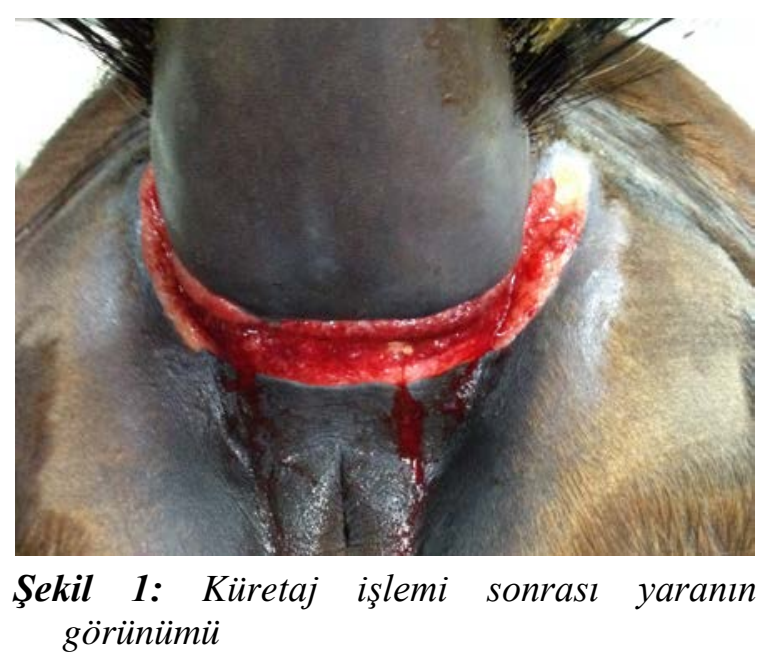

Figure 1: The appearance of the wound after the curettage. 


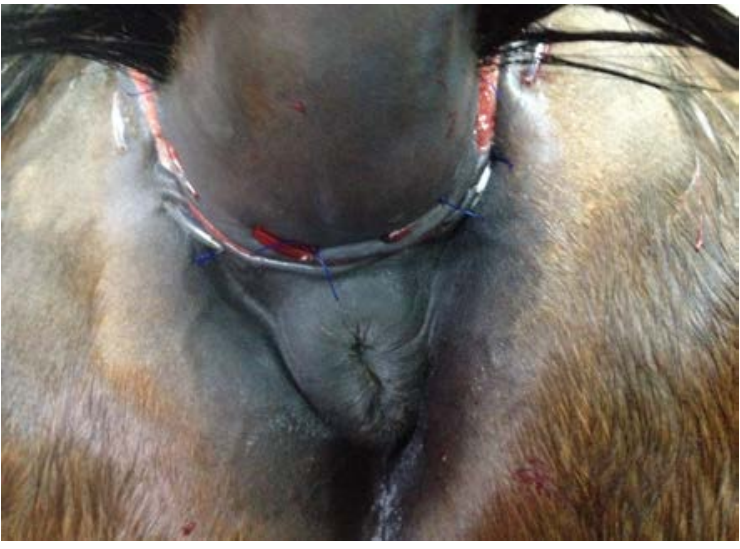

Şekil 2: Destekli yatay ' $U$ ' dikişi sonrası

Figure 2: After aided horizontal ' $U$ ' suture.

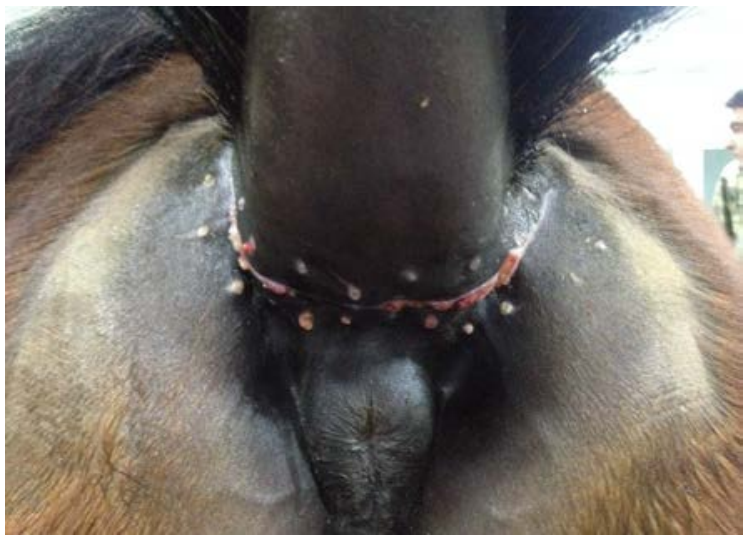

Şekil 3: 10. gün dikişler uzaklaştırıldıktan sonra

Figure 3: after ten days removed suture.

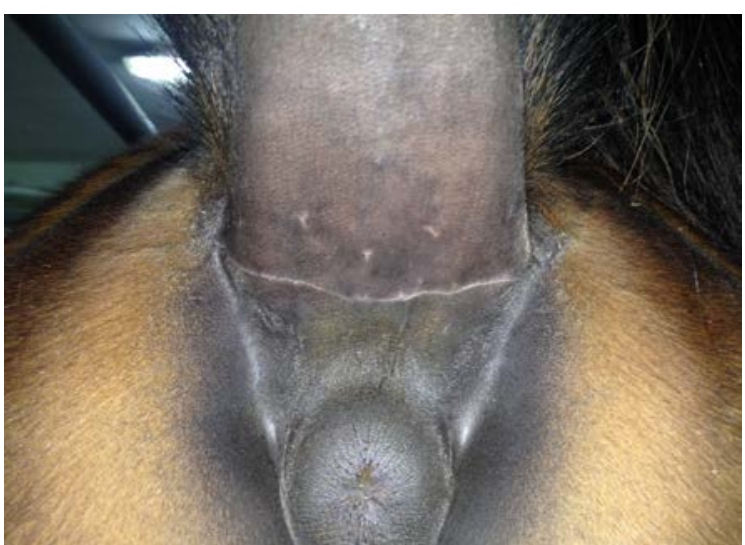

Şekil 4: 1,5 ay sonunda tamamen

iyileşmiş yara hattı

Figure 4: Completely healed wounds after 1.5 months.

\section{Tartışma}

Genç atların, yaşlı atlara göre daha çabuk iyileştiği bildirilmiştir ${ }^{3,7} .1 .5$ aylık bir periyotta derin olan bir yaralanmanın iyileşmesi hastanın
1 yaşında olmasının verdiği bir avantaj olabileceği düşünülmektedir.

Çok yaygın olarak kullanılan antienflamatuar ve nonsteroid gibi ilaçların yara iyileşmesini geciktirdiği bilinmektedir. Bu tür ilaçların kullanımında durumun takip edilmesi gerekmektedir. Atlarda yara tedavisinde öncellikle normal fonksiyonun kazandirılması daha sonra estetik açıdan düzgün olmasının sağlanması amaçlanmaktadır. Tedavi seçiminde birçok dış faktör göz önüne alınarak karar verilmelidir. Nekrotik dokuların ve yabancı cisimlerin uzaklaştırılması yara iyileşmesini olumlu yönde etkilediği bilinmektedir ${ }^{3,5}$. Yara üzerinde bulunan yabancı cisimler uzaklaştırıldıktan sonra bölgenin küretajı yapılarak yara hattında sikatrizasyonun sağlanması amaçlanmış ve belli bir bölümü primer olarak iyileştiği görülmüştür.

Primer yara iyileşmesinde dikiş materalinin daha az yangı reaksiyonu oluşturması bakımından sentetik bir malzemeden kullanılması önerilmiştir. Monoflament naylon dikiş materyallerinin özellikle deri kısmında ve gerilimin fazla olduğu durumlarda kullanılması tavsiye edilmiştir. Yara hattında gerilimin fazla olduğu durumlarda plastik küçük tüpler kullanılarak yatay ' $U$ ' dikişi uygulamasının faydalı olmakta$\mathrm{d} \mathrm{r}^{3,4}$. Bu olguda destekli yatay ' $U$ ' dikişi kullanılmış ve yara hattında plastik hortumların uç kısımlarının basınç nedeniyle dokuda küçük yaralanmalar oluşturduğu gözlenmiştir. Buna rağmen dikiş materyalinde herhangi bir gevşeme ya da açılmaya rastlanılmamıştır ve dokuyu istenilen şekilde karşı karşıya tutmayı başarmıştır.

Sonuç olarak; blanket kullanımında, atın vücut ölçülerine uygun boyutlarda bir ürünün kullanılması gerektiği ve üzerinde bırakıldığ durumlarda bu olgudaki gibi yaralanmalara sebebiyet vermemesi için dikkatli olunması gerektiği düşünülmektedir. Kuyruk kaidesinde oluşmuş olan bu yaralanmanın uygun şekilde tedavisi sonras 1,5 ay süren bir iyileşme süreci sonucunda tamamen iyileştiği belirlenmiştir. Etiyolojik yönden ender görülen bu olgunun raporlanarak paylaşılması amaçlanmıştır.

\section{Kaynaklar}

1. Amalsadvala T., Swaim S.F., 2006. Management of hard-to-heal wounds. Vet Clin North Am Small Anim Pract, 36, 693-711.

2. Binici Olmak Ders Kitabı 1. 2006. Türkiye Binicilik Federasyonu Eğitim Yayınları. 
3. Duncanson G.R., 2010. Veterınary Treatment For Working Equines. Chippenham, UK.

4. Görgül S., Seyrek-İntaş S., 2006. Dış Hastalıklara Giriş. U.Ü Vet. Fak. Yayınları, Bursa.

5. Hendrickson D.A., 2006. Management of Superficial Wounds. In: Fathman L. (Editors). Equine Surgery. 3rd Edition, Elsevier Inc., Philadelphia, syf 288-294.

6. Samsar E., Akın F., 2003. Genel Cerrahi. Medipres, Malatya.
7. Stashak T.S., Theoret C., 2008. Equine Wound Management. 2nd Edition, Blackwell Publishing, syf 181-183.

8. Tóth T., Broström H., Båverud V., Emanuelson U., Bagge E., Karlsson T., Bergvall K., 2011. Evaluation of LHP® (1\% hydrogen peroxide) cream versus petrolatum and untreated controls in open wounds in healthy horses: a randomized, blinded control study. AVS, 53, 45. 